\title{
DRAINAGE ADITS IN UPPER SILESIA - INDUSTRIAL TECHNOLOGY HERITAGE AND IMPORTANT ELEMENTS OF THE HYDROTECHNICAL INFRASTRUCTURE
}

\author{
StANiSŁaw DuŻy, GRZEGORZ DYDUCh, WOJCIECH PREIDL, GRZEGORZ STACHA \\ Silesian University of Technology, Faculty of Mining and Geology, Gliwice, Poland, \\ e-mail: Stanislaw.Duzy@polsl.pl, Grzegorz.Dyduch@polsl.pl, Wojciech.Preidl@polsl.pl, Grzegorz.Stacha@polsl.pl
}

\begin{abstract}
Adits played an important role in the hydrotechnical infrastructure for centuries. Initially, they were used mainly to drain wetland and supply water to the population. There were also inherent in the conduct of mining activities. They were used as exploratory, development and supply headings. Their usual function was to drain, ventilate and transport, and after the cessation of mining they became important elements of the hydrotechnical infrastructure in the transformed mining areas. The article presents issues related to the revitalization of the Main Key Hereditary Adit and Friedrich Adit as essential for the areas in which they are located. Both are hydraulic structures with the possibility of adaptation for tourism purposes. The need to consider some technical activities to be undertaken in this type of objects was pointed out, not only including aspects related to their proper protection so that they can continue to safely perform their function, but also to the preservation of their historical values. Due to their age and the method of drilling used in them, those headings are often included in the list of monuments and protected by law.
\end{abstract}

Key words: heading, drainage adit, hydrotechnical infrastructure, heading stability

\section{INTRODUCTION}

Adits played an important role in the hydrotechnical infrastructure for centuries. Initially, they were used mainly to drain wetland and supply water to the population [10]. With the development of civilization and the growing demand for efficient movement of large quantities of raw materials and tunnels they began to be used also for transport.

Adits were also inherent in the conduct of mining activities. They were used as exploratory, development and supply headings. Their usual function was to drain, ventilate and transport, and after the cessation of mining they became important elements of the hydrotechnical infrastructure in the transformed mining areas, preventing, among others, the ground water level from raising.

The oldest adits in Poland were related primarily to ore mining but also coal mining benefited from use of them. With the development of technology and the descent of the operation to the increasing depth, drainage tunnels were losing importance and were forgotten. In recent years, the role of these objects in the maintenance of proper water management even after the completion of mining activities has become increasingly recognized, and works related to the pro- tection and revitalization of them has been taken up in many cases.

The most famous buildings of this kind in Upper Silesia include the Main Key Hereditary Adit, which connected Zabrze and Chorzow, and Friedrich Adit in Tarnowskie Góry. These are objects of great interest not only from a historical point of view, but mainly because of the role they played and continue to play in maintaining an adequate level of groundwater.

\section{HISTORY OF CONSTRUCTION AND USE OF DRAINAGE ADITS IN UPPER}

\subsection{FRIEDRICH ADIT IN TARNOWSKIE GÓRY}

Ore mining in Upper Silesia was primarily associated with the areas of Garb Tarnogórski and Bytom. Zinc and lead ore with low silver content was mainly exploited here. The beginning of ore mining is associated with the activities of the Good, the Prince of Opole John II, who at the beginning of the sixteenth century gave a permission to explore and exploit the silver ores in the region of Tarnowitz (Tarnowskie 
Góry). At the same time he released the first land laws in Poland, the so-called Ordunek Gorny (year 1528). After the death of the prince in 1532, the areas of Bytom and Tarnowskie Góry were first taken over as a lease and then as property by the Margrave John George of Brandenburg [7], [8], [15]. During the heyday of this region, there were hundreds of wells and several mills. However, after the exhaustion of shallow deposits mining in the region of Tarnowskie Góry declined.

Construction of Friedrich Mine was an attempt to revive the ore mining in the area of Tarnowskie Góry. It commenced its operation in 1784. The initiators of its creation were: Anthony Frederick von Heinitz (then Minister of State of the Kingdom of Prussia) and Friedrich Wilhelm von Reden (then director of the State Mining Authority in Wrocław). Frederick Mine was a fiscal mine, in which lead and silver ore was mined. The work carried out in the areas of:

- Bobrowniki (the oldest, the operation was completed in 1897),

- Sucha Góra (open almost from the beginning of the mine, the operation was completed in 1904),

- urban - around Tarnowskie Góry (operation completed in 1913).

To enable effective drainage and the exploration of the mining field between Bobrowniki and Tarnowskie Góry (regions called: Sztolniowy, Publiczny, Suchogórski and Bobrownicki) in the years 1821-1835 the Frederick Adit (later called Kościuszko Adit) was dug. The outlet tunnels were located in the Drama river valley east of the village of Zbrosławice. The mouth of the underground part included a classical portal made of sandstone blocks (Fig. 1).

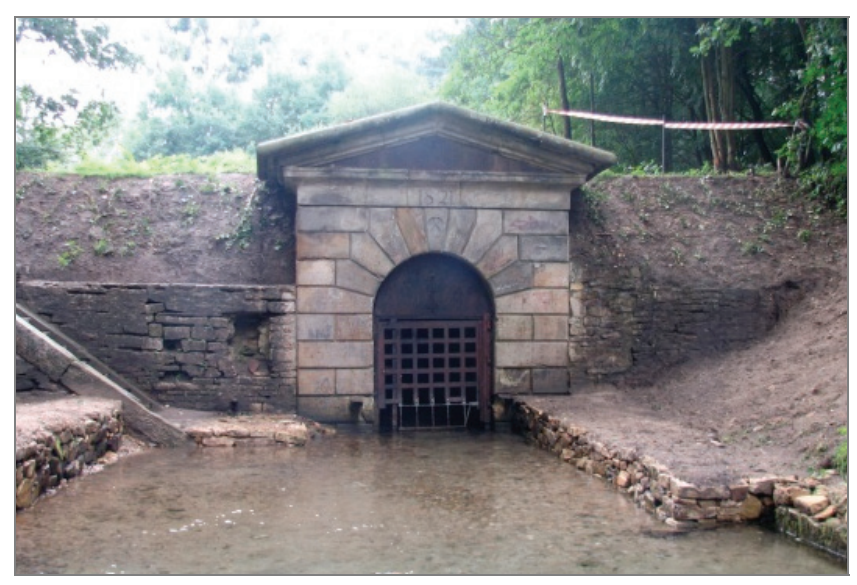

Fig. 1. The inlet portal of Frederick Adit (so-called Brama Gwarków)

The adit consists of four sections:

- I with a length of 50 lachters (104.5 m),

- II with a length of 559 lachters (1169.6 m),
- III with a length of 763 lachters (1956.4 m),

- IV with a length of 814 lachters $(1703.1 \mathrm{~m})$.

The total length of all sections of Frederick Adit was 2186 lachters (approx. $4568 \mathrm{~m}$ ). The underground part of the tunnel, with a length of $4568 \mathrm{~m}$, was drilled simultaneously with 14 faces accessible from small shafts, dug parallelly to the adit. Finally, for the purpose of ventilation and lighting, 25 small shafts (Ger.: Lichtschächte) were dug along the adit with 2 additional drainage shafts. Trenching excavation was carried out in very difficult geological conditions. There were intrusions of quicksand, embankment of weak roof rocks and a strong inflow of water into the excavation. For 10 years the mining works were directed by a senior superintendent (Ober Einfahrer) of the Mining Office in Tarnowskie Góry, Rudolf W.A. Carnall [12], [13].

All the work related to the drainage of the operating areas of the Frederick Mine was finished in 1880. The central dewatering system of the mine included a total of $14752 \mathrm{~m}$ excavation areas and operated until 1904. After the cessation of mining operations, the drainage system, which included the Frederick (Kościuszko) Adit, was used to supply water to the region of Tarnowskie Góry. The water intake built at Adolf (now Staszic) Adit functioned until 2001. Today, the water from this intage is transferred to the heading of the adit.

\subsection{MAIN KEY HEREDITARY ADIT IN ZABRZE}

Friedrich Wilhelm von Reden was also an initiator of the construction of the drainage tunnel in coal mines. During his trips abroad he became familiar with the system of adit drainage of shallow coal deposits, at the same time also being used for transport purposes [3]. That kind of solution was deployed in Wałbrzych (Lisia Adit, the construction was commenced in 1791) and in Zabrze (Main Key Heritage Adit).

Drilling of the Main Key Hereditary Adit (Hauptschlusselerbstollen) commenced on June 23, 1799. The intention of the mining authorities for the adit was to dewater the area between the coal mines: Queen Luisa in Zabrze and King in Chorzów and to perform the transport functions. Coal was floated to a special port built at the outlet and then, through the Kłodnicki Canal, to the Royal Foundry in Gliwice or further to the Oder.

In the years 1801-1806, the first stretch of Adit was made, from its mouth in the area of Miarki St. to the Queen Luisa mine. Then the excavation works started in the King mine in Chorzow. It was completed in 1863. 


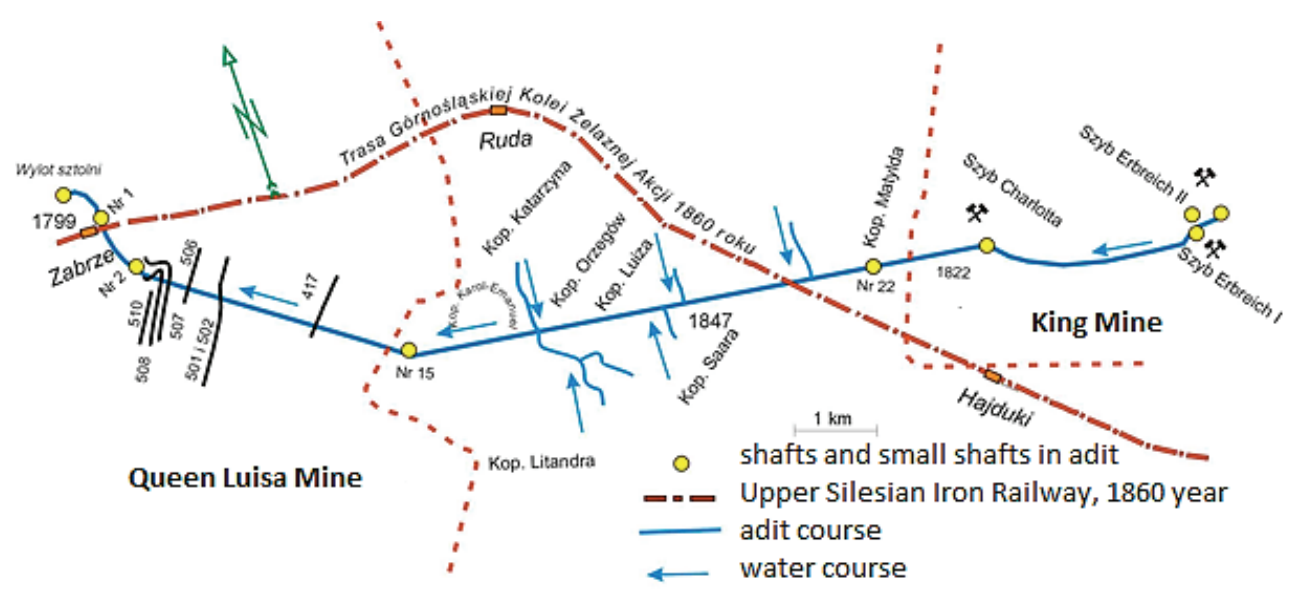

Fig. 2. Diagram of the Main Key Hereditary Adit with marked mining assignments [9]

In the years 1850-1860, many branch tunnels dug to drain collier mines (private) were located between the state institutions "Queen Luisa" in Zabrze and "King" in Chorzow. Up to $700 \mathrm{~m}$ such sidings were drilled yearly, merging the Main Key Hereditary Adit with the mines: Franciszek, Quintofore, Saara, Eintracht, Belovsegen, Katarzyna, Karol-Emanuel and Lithandra (Fig. 2) [9], [11]. The adit together with the so-called adit section of the Kłodnicki Canal became an important waterway for the transport of coal. The project involved the construction of three passing places along the route and three ports for loading coal. The first boats of coal rolled down the Main Key Hereditary Adit to the Kłodnicki Canal probably in 1806 .

The construction of the section of the canal between the steel mill in Gliwice and the mouth of the adit in Zabrze was completed that year (in 1822 the whole Kłodnicki Canal with its estuary in Koźle was put into operation). In 1810 a navigable part of the canal with a length of approx. $2.5 \mathrm{~km}$ was completed. The adit quite soon lost its importance as a transportation route. This was due to a number of factors, among which the most important were:

- construction of roads for faster communication and transport: Kronprinz Route in 1838 linking Zabrze with Chorzów and construction of the Upper Silesian Iron Railway in 1860,

- exhaustion of deposits in the area above the adit,

- improvement of drainage in mines due to the introduction of large-scale steam pumps and later electricity,

- subsidence of the drift heading due to the operations carried out underneath the adit.

Therefore, 1842 can be assumed to be the last in the utilitarian "life" of the adit. After the construction of a section of the tunnel parallel to the timbered brick trough that settled down, which was done in the 1850s, the adit served only the hydrotechnic role, draining water from the $40 \mathrm{~m}$ level to the river Bytomka, therefore, not so much dewatering the coal as draining layer of overburden and preventing the flooding of the area of today's Zabrze town centre. In the 1850s, its outlet at Miarki St. was finally closed, but the excavation was never filled.

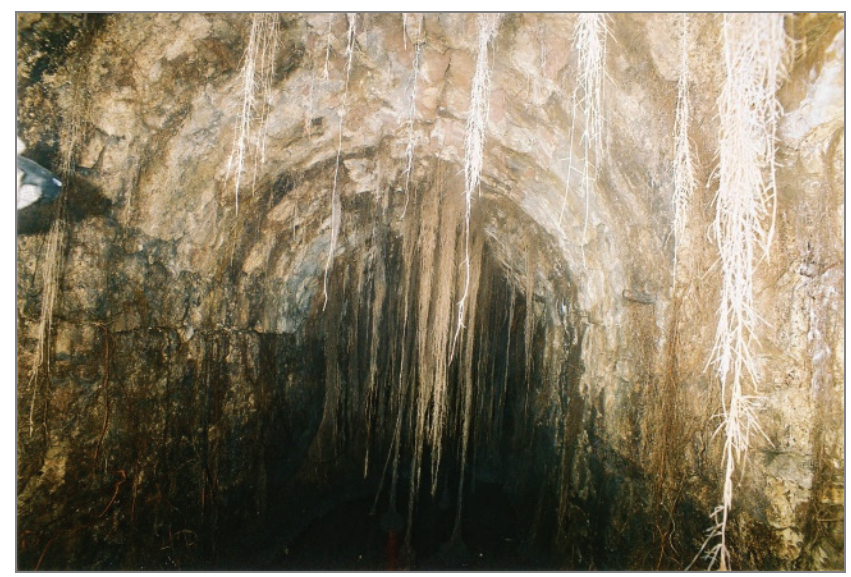

Fig. 3. A view inside the adit with roots overgrowing the support wall (Photo: W. Preidl [14])

During the work undertaken in order to revitalize the tunnel as a tourist destination, it was found that at the stretch from Miarki St. to the Carnall shaft the adit tunnel was filled with coal slime and other deposits up to the height of 3 metres where the water flows on the surface. The support of the adit is overgrown by tree roots (Fig. 3) [5]. At the same time, it was found that at the length of the explored section there are connections to storm sewers, whose presence was not documented (Fig. 4) [14]. 


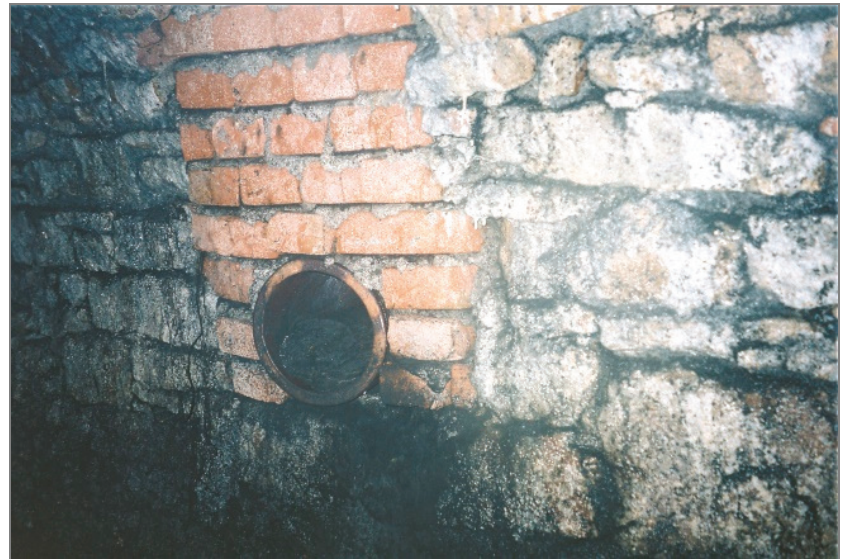

Fig. 4. Sewage connection to the adit (Photo: W. Preidl [14])

\section{ADITS AS HYDROTECHNICAL HEADINGS AND THEIR INFLUENCE ON ENVIRONMENTAL SURROUNDINGS}

Within the concerned system of groundwater based on the major surface water courses, the direction of water run-off is determined mainly by the depth of the location of the elements of that system. There is a close relationship between the height of the groundwater table and the height of the local drain base, which is generally the surface of water in a nearby drainage watercourse of the basin area. The layout of the water table of naturally drained aquifers supplied by the infiltration of precipitation is shaped mainly by the deepest surface watercourses as well as open sewers (border elements of the drain). The local surface drain base determines the maximum height to which the stabilized groundwater table can rise in the catchment area.

In the present area of Zabrze and Tarnowskie Góry that function is fulfilled by the old mining tunnels of the Main Key Heritage Adit in the region of Zabrze and the Frederick (Kościuszko) Adit in the region of Tarnowskie Góry and partly Bytom.

\subsection{THE FREDERICK (KOŚCIUSZKO) ADIT IN TARNOWSKIE GÓRY}

Surface waters in the area where the Tarnowskie Góry and Bytom subsurface structures are located belong to the river basin of the following rivers: Drama, Stoła and Szarlejka. Drama and Stoła are in the Odra river basin, while Szarlejka is in the Vistula basin. Sources of these rivers are located at the altitude of 290-320 m above the sea level. Drama has its origin in the vicinity of Stare Tarnowie and is powered by, among others, the waters of the Frederick Adit. Stoła has its source in the northern part of the city Tarnowskie Góry, and is also periodically supplied with water from old mine headings. Water states of both rivers fluctuate significantly. Szarlejka flows from the area of Blachówka the district of Bytom, formerly supplied with water discharges from an adit called Od Szarlejki.

The hydrogeological conditions in the area of Frederick (Kościuszko) Adit are significantly affected by surface watercourses, i.e., the river Drama, also called Rów Repecki, which is supplied by Starotarnowicki Stream at the western edge of Repecki Park. South of

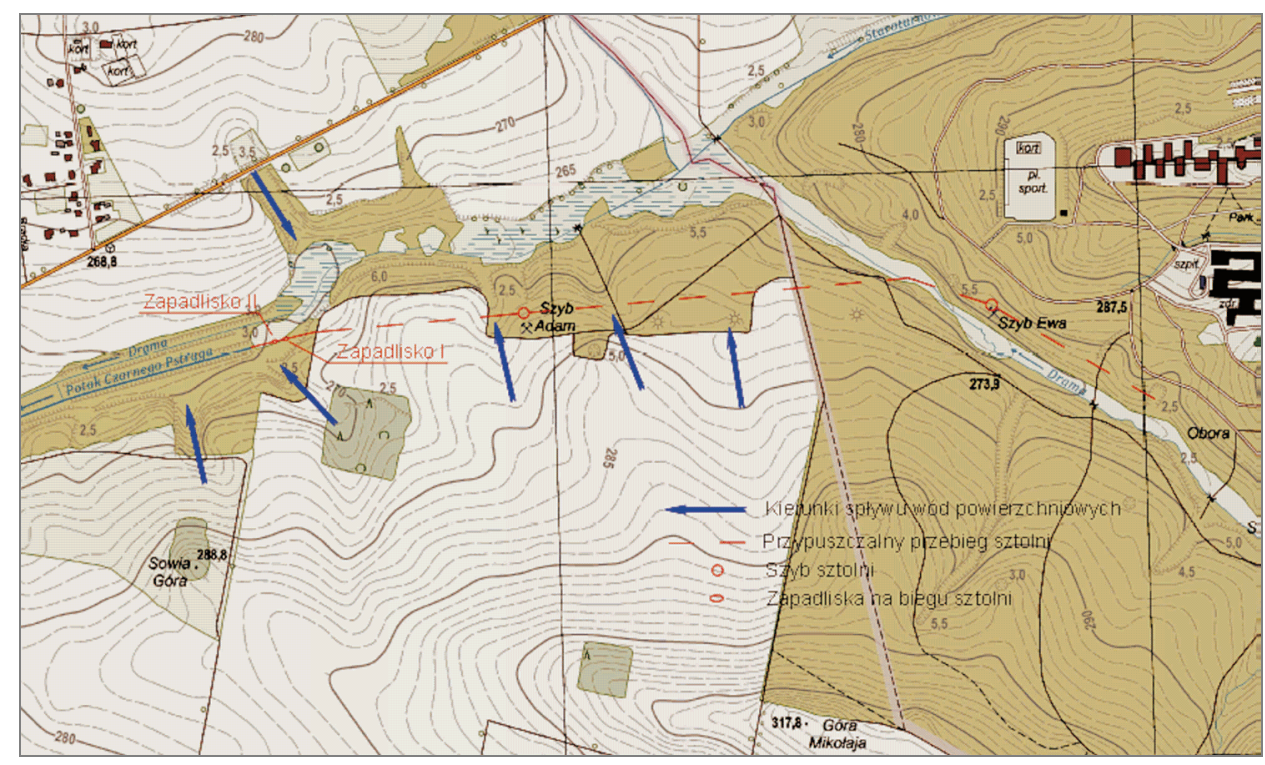

Fig. 5. Diagram of watercourses in the area of the Frederick (Kościuszko) Adit (Duży et. al., [7]) 


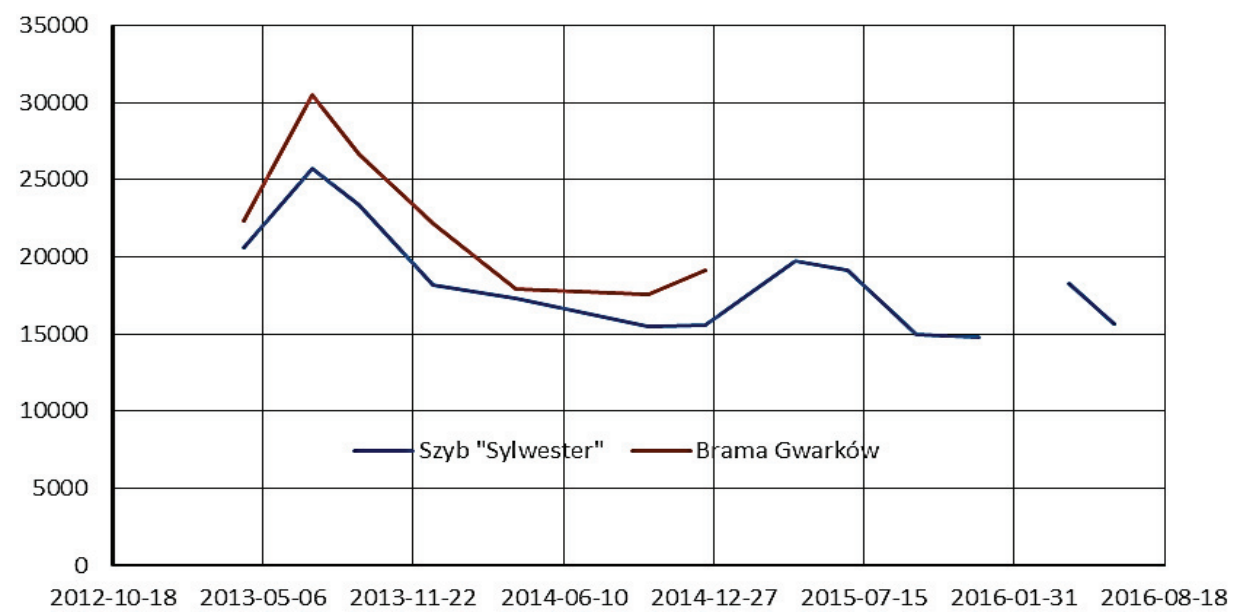

Fig. 6. Water flow graph in the Frederick (Kościuszko) Adit (acc. to the data from the Society of Tarnowskie Góry Supporters - SMZT) (Duży et. al., [8])

Drama connection with Starotarnowicki Stream the river is supplied from the north by an unnamed drainage watercourse gathering water from the area north of the road Zbrosławice - Tarnowskie Góry. North of Góra Sowia (Owl Mountain), Drama is powered by water discharged from the Frederick (Kościuszko) Adit (Fig. 5).

The impact of climate changes is crucial to the intensity of the flow of water into the headings of the former Frederick mine, and thus, the same for the Frederick (Kościuszko) Adit.

Analysis of measurements of water flow conducted in the Sylwester Shaft and at the outlet of the tunnel (the Miners' Gate) showed large differences in the amount of water flowing through the cross section: from 17 to 30 thousand cubic metres a day (Fig. 6).

These differences are probably the result of water penetration through the housing of the tunnel in the section between the Sylwester Shaft and the exit of the tunnel at the Miners' Gate. It can be stated with high probability that this process is clearly influenced by two factors: the geomorphologic structure of the terrain and the technical state of the stone support of the tunnel. The relief in the area of the adit is strongly folded. From the south, the Drama valley is surrounded by hills called Góra Mikołaja, Wapienna Góra and Sowia Góra, and from the north, the hilly-shaped terrain descends toward the road between Zbrosławice and Tarnowskie Góry. From the north, the rainwater flows into the river Drama through openings made in the embankment topped by the road between Zbrosławice and Tarnowskie Góry. Both of these areas are the natural catchment area of the river in the direction of Drama and the heading of the adit, which in its initial section is relatively shallow. The thickness of the overburden in the region is from 2 to 5 meters. It should be noted that there are probably additional sources of water within the outlet area of the adit. There is a heading of the Krakowski Adit which was drilled in the vicinity of the outlet of the Frederick (Kościuszko) Adit as early as in the year 1568. The tunnel was intended to extend to the length of 270 lachtes $(513 \mathrm{~m})$. In the eighteenth century there were attempts to revive the adit, but after a preliminary investigation this idea was abandoned as the design and the construction of the Frederick (Kościuszko) Adit was commenced [13]. The valley of Drama in the area of the Miners' Gate is overgrown with vegetation, mainly being bushy and swampy, while the rim of the valley is a narrow strip of mixed forest, deciduous and coniferously dense, with a bushy shell and the slopes of the hills are farming fields. Rainwater can run down without any major obstacles to the valley of Drama. In previous years there were cases of mudslides that came down from the slopes to the adit and the river Drama.

Closure or self-filling of the Frederick Adit led to serious consequences not only for the Historic Silver Mine in Tarnowskie Góry but also for the northern districts of Bytom and the Szarlejka river basin. As an example may serve the case of a year 2008 when a spontaneous caving of the adit support within its final section caused the damming to such extent that it prevented the operation of the floating route in the Black Trout Adit and threatened flooding of the underground headings at the touristic route.

\subsection{THE MAIN KEY HEREDITARY ADIT IN ZABRZE}

After the exploitation of the Zabrze Zachód Mine was terminated and its drainage system was made 
defunct, the underground watercourses gradually returned to a state similar to the original, in which their circulation within the basin is again based on their gravitational confluence to the main surface watercourses. It can be assumed that the groundwater level generally returned to its original height. The outflow conditions of water in catchment areas being subjected to the influence of mining have undergone farreaching changes during the many decades since the establishment of the Queen Luisa Mine (Zabrze Zachód). Some of these transformations have worsened the conditions of the water runoff. These include the occurrence of morphologic post-exploitational pans caused by subsidence of the landmass or by earthworks. Sealing of riverbeds and their retrenchment negatively affected the draining conditions of aquifers. In this regard, some of them are now partially detached from the natural circulatory water flow in the basin.

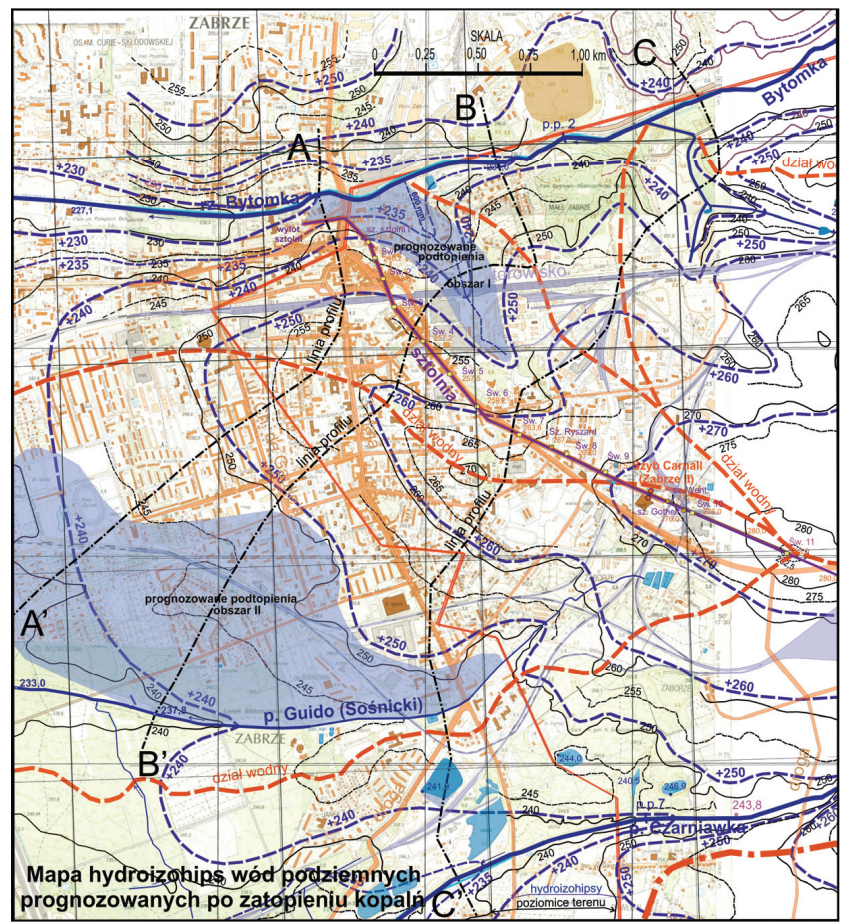

Fig. 7. Map of a predictied position of the underground watercourse table within the area of the adit with the possible areas of flooding [6]

The process of rising of the water table will continue until a balance between the inflow and supply on the one hand and the drain and balance loss on the other hand is achieved. After the sinking of the mine and re-establishment of the aquifers, the main surface watercouses (Bytomka, Czarniawka and Guido) consitute the base for groundwater and surface water drainage in the catchment areas. Currently, these courses act as a receiver for surface and, partially, quaternary waters but do not work as a drain (receiver) for carboniferous waters. The effectiveness of surface and underground runoff in the catchment area is the main factor determining the position of the groundwater table. A river bed determines the base of the drain for ground water remaining in hydraulic communication with the river. The level of accumulation of water in the catchment area is determined by the position of the local drain base. Damming the main valley will affect the water states in the side valleys.

Water filling up the underground tank joins the active water exchange flow where it is subjected to the influence of surface drainage and evaporation and after filling the depression cone the outflow conditions of water in the basin stabilize. The table of an underground water reservoir is being subjected to modifications conditioned by the morphology of the terrain and spatially diversified supply and drainage. The runoff conditions in the catchment constitute the decisive factor in the height of the water table (Fig. 7) [6].

\section{ASSESSMENT OF RISK TO THE SURFACE AND ITS INFRASTRUCTURE IN THE CASE IF THE SUPPORT OF THE ADITS LOSES ITS STABILITY}

The fact that the Frederick (Kościuszko) adit has a shallow location in its initial section, as measured at the outlet of the tunnel (Miners' Gate), had a decisive influence on the increased risk of the possibility of discontinuous deformations on the surface. The possibility of such threat was confirmed during fieldwork in a form of sinkholes. The first appeared in 1962, and the second in 2008. After a visit to the site, it was found that both sinkholes appeared as results of breakages in roof sections of the support. The sinkhole of 1962 is now partially buried and the support tunnel in this section is restored, however the sinkhole from 2008 is only protected by wooden cabinet anchors and the area around the sinkhole is fenced and marked as a danger zone.

In the case of the Main Key Hereditary Adit the sinkhole threat occurred in 2012, during the investment works in the area of the outlet tunnel. A defect occurred in the stone support as it displaced towards the heading, causing a risk of losing stability. The situation was noticed in time, and the heading was pre-secured. 
It can be assumed that the sinkholes generate voids located at a depth of up to $100 \mathrm{~m}$. Those voids are often associated with tunnel headings that were improperly eliminated or left in its natural state [6].

For the purpose of estimating the probability of sinkholes as a result of loss of stability of the inlet section of the tunnel support, the Chudek-Olaszowski method is used most frequently [1].

The section of the tunnel being analyzed runs almost horizontally at a depth of $0-15 \mathrm{~m}$ counting from the roof of the heading. The heading was dug in the layers of sand, loam or clay as well as of the dolomite layer in the roof section (Frederick Adit) or sandstone (Main Key Hereditary Adit), which is residual beneath the overburden. Taking into account the above information and including the depth of the heading, it should be explicitly stated that a possible collapse in the area would include the loose layer of overburden.

Thus, in the light of the method used, a loss of stability of the support of the heading would beyond any doubt result in an appearance of a sinkhole on the surface. The sinkhole would appear in the area where the loose overburden is located.

\section{ASSESSMENT OF THE SAFETY OF THE SUPPORT IN THE ANALYZED SECTIONS OF THE ADITS}

Underground headings used over a long period of time, especially when the access to them has been cut off for a significant time, usually have the supports with a large and often very uneven degree of technical wear. In this situation, load-bearing capacity of the support can be treated as a random variable with a certain probability distribution or a certain range of variation. Similarly, the state of the rock mass in the vicinity of the heading with a long-term existence is progressive and the degradation is often very different in each section. In that case, the parameters describing the current state of the rock mass can also be considered as random variables with a certain probability distribution or range of variation. Assuming that the parameters determining the stability of the historic underground headings are random variables, it is advisable to use a probabilistic method to analyze the stability of the excavation.

In theory of reliability and security of structures based on a probabilistic analysis, the likelihood of loss of stability can be the measure of reliability. The size of the probability of impact is influenced by the so- called safety margin (the difference in capacity of the structure and its load) and the variance of basic data to determine the stability of the heading.

The evaluation of safety of a structure is a solution to a two-stage probabilistic approach based on the assumption that the failure condition can be written as:

$$
Z_{0}=P_{0}-q_{0} \geq 0
$$

where:

$Z_{0}$ - safety margin,

$P_{0}$ - capacity of the support,

$q_{0}$ - load of the support.

The Cornell's reliability index $(t)$ is assumed to be a measure of safety:

$$
t=\frac{\bar{P}_{0}-\bar{q}_{0}}{\sqrt{s_{P_{0}}^{2}+s_{q_{0}}^{2}}}
$$

The value of the cumulative distribution coefficient reliability $p(t)$ is the probability of the safety of the structure, while the value $[1-p(t)]$ is the probability of failure of the structure (loss of stability of the support).

In this method, the conditions of reliability and safety are used, such as:

$$
p \leq p_{a}
$$

where:

$p$ - probability of a loss of stability,

$p_{a}-$ an accepted level of probability of a loss of stability.

Corridor heading sections can be assigned with one of 4 classes on the basis of the relationship between their behaviour and the probability of a loss of their stability, namely [4]:

- Class I $-p \leq 0.05$ - good conditions of heading stability,

- Class II $-0.05<p \leq 0.15$ - satisfactory conditions of heading stability,

- Class III $-0.15<p \leq 0.30$ - permissible conditions of heading stability,

- Class IV $-p>0.30$ - dangerous state, inadmissible conditions of heading stability.

In order to safely meet its technological requirements, a corridor heading should be classified as Class I or II. Conditionally, it is permitted to qualify for Class III, but in this case its supervisor should be ready to carry out repair works or limit the scope of its use.

In order to raise the class of the conditions for maintaining the stability of a heading, it is necessary to increase the security margin of the structure, which can be achieved by increasing the capacity of the support or reducing its load. Improving the conditions for 
maintaining the stability of the excavation can also occur through repair of the support, which reduces the volatility of its capacity, or by reducing the volatility of its load by carrying out specific preventive activities. Table 1 summarizes the results of the analysis of the eligibility of individual sections of the analyzed adit, taking into account the conditions for maintaining the stability of underground headings while Fig. 8 shows the example of the Frederick Adit with its distribution of sections along the tunnel and their assignments for individual classes.

Table 1. A summary of results of the adit stability analysis along its routes

\begin{tabular}{|c|c|c|c|c|c|}
\hline \multirow{2}{*}{ Adit name } & \multirow{2}{*}{$\begin{array}{c}\text { Length } \\
{[\mathrm{m}]}\end{array}$} & \multicolumn{4}{|c|}{$\begin{array}{c}\text { Total length of sections } \\
\text { assigned with classes [m] }\end{array}$} \\
\cline { 3 - 6 } & & $\mathrm{I}$ & $\mathrm{II}$ & $\mathrm{III}$ & $\mathrm{IV}$ \\
\hline Frederick & 1268 & 703 & 440 & 80 & 45 \\
\hline $\begin{array}{c}\text { Main Key } \\
\text { Hereditary Adit }\end{array}$ & 2350 & 510 & 970 & 690 & 180 \\
\hline
\end{tabular}

Visible effects of material degradation can be aesthetic defects, but can also indicate a loss of some of properties and affect the stability of the structure. To assess whether these threats are an indication to commence repair works, a study should be conducted to define their scope. When taking actions related to the securing of objects of underground structures and repair, it is recommended to perform the following actions [16]:

- inventory of the heading,

- diagnostics of the support and assessment of the safety of the heading,

- formulation of the security requirements as well as usability and historical values,

- analysis of geological and mining conditions,

- calculation of the interaction parameters between the rock mass and the support,

- calculation of the static stability of the heading,

- development of a security system of the heading,

- development of a system for monitoring of the heading,

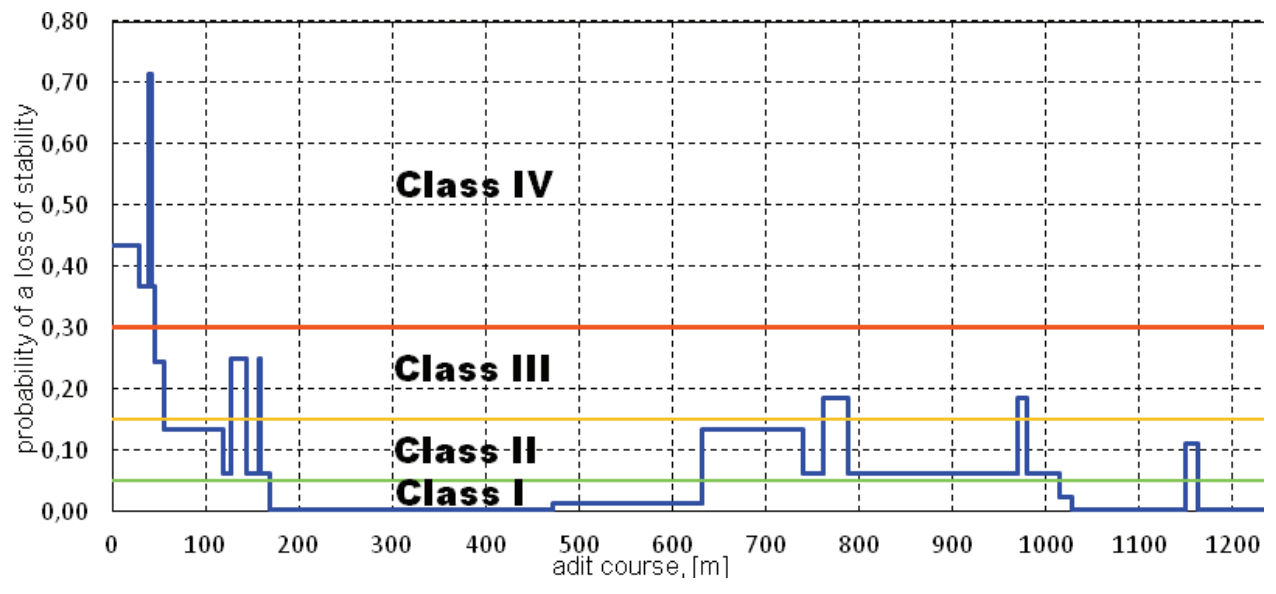

Fig. 8. Distribution of sections along the course of the Frederick Adit assigned to particular classes

\section{ESTABLISHMENT OF NECESSARY ACTIVITIES IN ORDER TO SECURE THE HISTORICAL UNDERGROUND HEADINGS}

The choice of methods to repair support structures depends on many factors, among which the most important are:

- the type of material used,

- environment affecting the structure,

- type of the confirmed damage,

- additional demands on the appearance of the object.
- formulation of guidelines for the continued safe use of the heading.

In order for the chosen technology to bring the desired result, it must be applied by the means specific to the underground environment. The resistance to the prevailing temperature and high humidity is particularly important in this respect.

The issue of the security of the heading while retaining its historical character, as any engineering problem, requires an individual approach due to the high variability of the engineering and geological conditions along its course as well as its microclimate. Additionally, all plans of works in the Main Key Hereditary Adit should take into account its historical 
character. The requirements for securing a target hydrotechnical heading system with historical values, such as the Main Key Heritage Adit, and the Frederick Adit is shown in Fig. 9.

In order to improve the investment process to secure the excavation it is proposed to apply repeatable modules, as shown in Fig. 10.

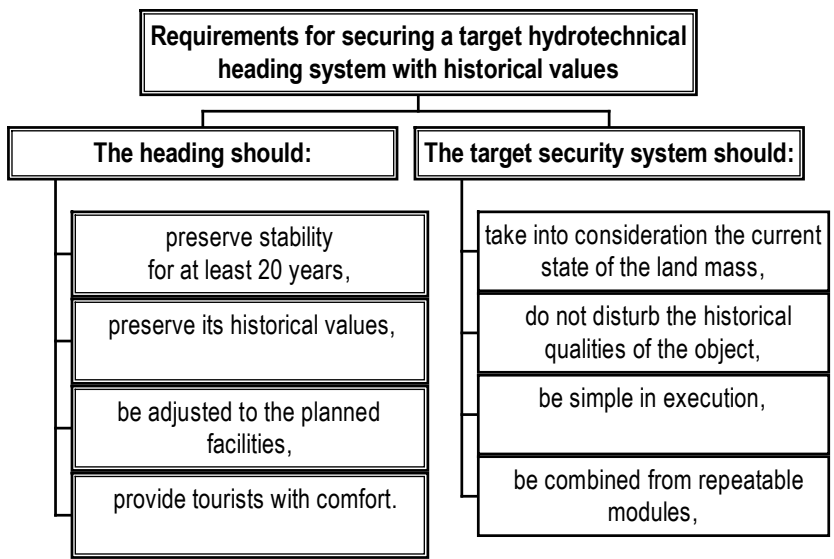

Fig. 9. Requirements for securing a target hydrotechnical heading system with historical values [16]

\section{SUMMARY}

Hazardous conditions being the result of mining exploitation may occur in the post-mining areas even many years after its completion. The possibility of formation of sinkholes caused by voids left after the end of exploitation, or appearing as a consequence of secondary processes under the surface, which occur at small depths, or as a result of changes in the hydrogeological conditions, is particularly dangerous.

Assessments of stability of headings left in the ground after the operation ceases depend on many factors which can be determined only with a certain approximation. The main factors which may decide on information uncertainty may include:

- variability of structure and properties of the rock resulting from the processes of stress and deformation occurring during and after operation.

- variability of dimensions of cross-sections of the excavation along its course due to peeling or em-

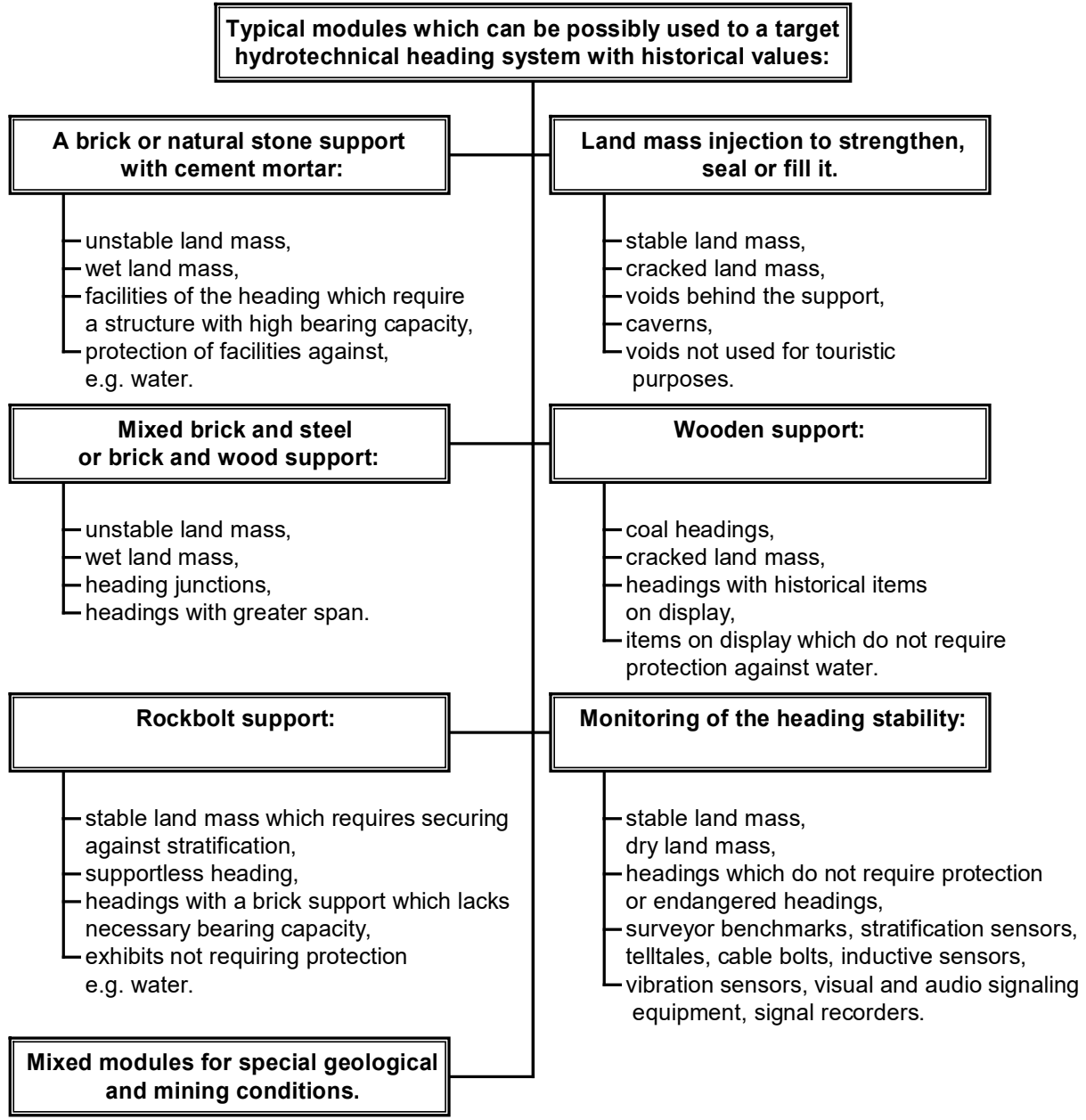

Fig. 10. Typical modules which can be possibly used to a target hydrotechnical heading system with historical values [16] 
bankment of the land mass or partial filling of the heading, etc.,

- variability of stress and deformation force fields in the land mass resulting from changes in rock properties, geological conditions, mining conditions and the impact of developed underground and surface infrastructure,

- high and varying degrees of technical wear of the heading support due to a long period of its existence and the adverse environmental effects.

Given the above mentioned issues, it is expedient to consider the possibility of use of probabilistic methods, taking input parameters as random variables, while the probability of an adverse condition may be the measure of a risk of loss of stability.

The proposed classification of conditions to maintain the stability of the heading can be used as a tool to:

- assess the safety of the heading,

- estimate the necessary scope and costs of corrective and preventive actions,

- preliminarily assess the suitability of a given area for further development,

- determine the schedule of corrective and safety actions in a specific area of the heading to reduce the risk of a caving.

The choice and design of a plan to secure a historic underground heading is associated with the necessity to solve many technical, geomechanical, cultural and economical problems.

\section{REFERENCES}

[1] Chudek M., JANuSz W., Zych J., Studium dotyczace stanu rozpoznania tworzenia się i prognozowania deformacji nieciagtych pod wpływem podziemnej eksploatacji złóż, Zesz. Nauk. Pol. Śl., Ser.: Górnictwo, Vol. 141, Gliwice 1988, (in Polish).

[2] CHUDEK M., Geomechanika z podstawami ochrony środowiska górniczego i powierzchni terenu, Wyd. Politechniki Śląskiej, Gliwice 2002, (in Polish).

[3] Clarke M., Sztolnie splawne w górnictwie w Anglii. Międzynarodowa Konferencja „Lisia Sztolnia” w Wałbrzychu jako zabytek techniki europejskiego dziedzictwa kulturowego, Wałbrzych, 20 września 2001, 43-51, (in Polish).

[4] DuŻY S., Ocena stopnia bezpieczeństwa wyrobisk korytarzowych zlokalizowanych na terenach pogórniczych, Zeszyty Naukowe IGSMiE PAN, 2016, No. 94, 27-39.
[5] DuŻY S. et al., Wykonanie ekspertyzy dotyczacej przyczyn powstania i sposobu usunięcia awarii obudowy Gtównej Kluczowej Sztolni Dziedzicznej na odcinku przebiegajacym pod ulica K. Miarki w Zabrzu, Praca naukowo-badawcza NB-264/RG-4/2012, unpublished, (in Polish).

[6] Duży S., Pozzi M., CEMPIEl E. et al., Glówna Kluczowa Sztolnia Dziedziczna - określenie oddziaływań i zagrożeń dla środowiska wraz z koncepcja działań ograniczajacych negatywny wptyw obiektu na ekosystem Miasta Zabrze, Praca naukowo-badawcza NB-178/RG-4/2013, unpublished, (in Polish).

[7] DuŻY S. et al., Ocena stanu technicznego obudowy Sztolni "Fryderyk" w Tarnowskich Górach pod katem jej docelowej rewitalizacji, Konferencja Budownictwo Infrastruktura Górnictwo 2016: "Zrównoważony rozwój terenów górniczych i pogórniczych”, Kraków, 21-22 listopada 2016, (in Polish).

[8] DuŻy S. et al., Opracowanie stużące podjęciu działań dla zahamowania naturalnej degradacji końcowego odcinka historycznej sztolni „Fryderyk” (,,Kościuszko”) w Tarnowskich Górach, z wylotem znajdujacym się na terenie Ptakowic gm. Zbrostawice, Praca naukowo-badawcza NB-189/RG-4/2016, unpublished, (in Polish).

[9] Duży S., Jurkiewicz J.G., PreidL W., Możliwości wykorzystania Głównej Kluczowej Sztolni Dziedzicznej, jako zabytku kultury technicznej i atrakcji podziemnej trasy turystycznej Skansenu Górniczego „Królowa Luiza” w Zabrzu, „Dziedzictwo i historia górnictwa oraz możliwości wykorzystania pozostałości dawnych robót górniczych", Politechnika Wrocławska, Wrocław, 2006, 52-62, (in Polish).

[10] Grewe K., Lich am Ende des Tunnels. Planung unad Trassierung im antiken Tunenelbau, Verlag Philipp von Zabern, Mainz am Rhein, 1998.

[11] Kossuth S., Wielkie sztolnie odwadniające w Górnośląskim Zagłębiu Węglowym, Przegląd Górniczy, 1962, No. 7-8, 460-465, (in Polish).

[12] Moszny J., Gtęboka sztolnia "Fryderyk" i Sztolnia “Czarnego Pstraga" w Tarnowskich Górach, Międzynarodowa Konferencja "Lisia Sztolnia" w Wałbrzychu jako zabytek techniki europejskiego dziedzictwa kulturowego, Wałbrzych, 20 września 2001, 64-69, (in Polish).

[13] Moszny J., Rola i znaczenie sztolni odwadniajacych w górnictwie tarnogórskim. Materiały Sympozjum 45 lat dziatalności Sztolni "Czarnego Pstraga" w Tarnowskich Górach, Stowarzyszenie Miłośników Ziemi Tarnogórskiej, Tarnowskie Góry, 2002, 25-39, (in Polish).

[14] PreIDL W., Ocena stanu technicznego obudowy Gtównej Kluczowej Sztolni Dziedzicznej na odcinku zabrzańskim, Górnictwo i Geoinżynieria, Kwartalnik AGH, 2006, Vol. 4, 97-102.

[15] StrZalKowska E., PreidL W., Wybrane zabytki Tarnowskich Gór, Budownictwo Podziemne i Tunelowe, 2016, No. 4, 19-26.

[16] Uтко S., DuŻY S., Metoda doboru sposobu zabezpieczenia $i$ adaptacji zabytkowych obiektów podziemnych, Budownictwo Górnicze i Tunelowe, 2016, No. 2, 35-43. 